\title{
FERTILITY IMPROVEMENT IN AUTOTETRAPLOID SORGHUM
}

\section{SORGHUM ALMUM DERIVATIVES}

\author{
H. DOGGETT \\ E.A.A.F.R.O., Serere, Uganda
}

Received 12.iii.64

\section{INTRODUCTION}

LARGE fertility differences which are under genotypic control have been demonstrated in autotetraploid cultivated sorghum (Doggett, I964), but none of the seed-set levels recorded so far has been high enough to serve as a basis for the development of tetraploid sorghum as a grain crop. The best levels have been 70-75 per cent., as compared with diploid levels of 9o-95 per cent. Empirical hybridisation between a wide range of autotetraploid cultivated sorghums might well lead to the discovery of gene combinations giving better fertility, but this is a shot-gun approach, with no certainty of success. A look at the fertility levels available in the wild tetraploid sorghums of the Halepensia group (Snowden, I 955) seemed worth while first.

Sorghum halepense (Johnson grass) is a notorious weed in America and elsewhere. Although Johnson grass occurs in North Africa along the Mediterranean littoral, it is geographically isolated from East Africa, and its introduction here would be an irresponsible act. No such objection applies to Sorghum almum, which is less strongly stoloniferous and aggressive. The studies reported here have therefore been confined to this one member of the Halepensia, Sorghum almum (plate I).

\section{MATERIALS AND METHODS}

The bulk $S$. almum seed for the work reported here was kindly supplied by G. R. Horrell, pasture agronomist at Serere. The stock had been imported from a South African seed firm a few years before. Lines A and B, and the derivatives of the cross $\mathrm{A} \times \mathrm{B}$, are the same autotetraploid grain sorghums considered in the earlier paper (Doggett, 1964).

Seed-sets were obtained from counts made on a minimum of 200 sessile spikelets from the middle panicle branches of each plant. The percentage seed-set is the proportion of these sessile spikelets which contain seed.

\section{FERTILITY IN SORGHUM ALMUM}

(i) Fertility differences between $\mathrm{S}$. almum lines

The Sorghum almum bulk at Serere showed a wide range of fertility, and selection was begun to extract high seed-set lines. Fifteen such lines, still at an early stage of selection, were included in a trial with two diploid lines and a range of autotetraploid cultivated sorghums. Part of this trial has already been reported (Doggett, I964). In 
table $\mathrm{I}$ is shown the seed-sets of the almum lines, the diploids and the best entry of the autotetraploid cultivated sorghums, $\mathrm{T} 32$. The diploid form of the latter is cultivated in Serere district.

TABLE I

Seed-sets of $\mathrm{S}$. almum lines, diploid lines ( $\mathcal{N}_{I}$ and $S A$ 2) and the autotetraploid cultivated sorghum $T_{32}$ (Ig6I)

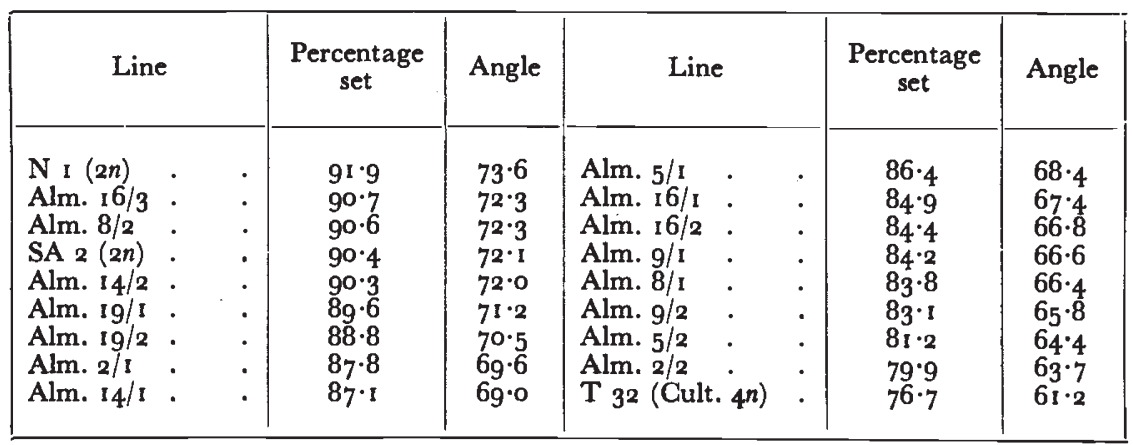

Differences required for significance on the Duncan test at $\mathrm{P}=0.05$ (angular values).

\begin{tabular}{|c|c|c|c|c|c|c|}
\hline$p$ & 2 & 4 & 6 & 8 & 10 & 16 \\
\hline & $5 \cdot 0$ & $5 \cdot 4$ & $5 \cdot 6$ & $5 \cdot 7$ & $5 \cdot 8$ & $6 \cdot 0$ \\
\hline
\end{tabular}

The heritability estimate for this part of the trial in table $\mathrm{I}$ is $h^{2}=75$ per cent.* The figures show that there are fertility differences between the $S$. almum lines, and the two lines $8 / 1$ and $8 / 2$, derived from a single plant two generations previously, are just significantly different from each other at $P=0 \cdot 05$. Some of the $S$. almums do not differ in fertility from the diploid cultivated sorghums. Even if it is conceded that pollen interference may have reduced the diploid set, it is clear that the fertility of some $S$. almum lines is within 5 per cent. of diploid values, since a mean diploid set of 95 per cent. is very good at Serere. Further, their percentage sets are much above any autotetraploid cultivated sorghum seed-sets previously obtained (Doggett, 1964).

(ii) The inheritance of high seed-set in S. almum crosses

Deliberate hybrids were made between $F_{5}$ lines of the cultivated autotetraploid cross $(\mathrm{A} \times \mathrm{B})$ and the unselected $S$. almum bulk. These $(A \times B) F_{5}$ lines had been selected for high seed-set since the $F_{3}$ generation. In addition, natural crosses occurred between others of these * Calculated from $h^{2}=\frac{b_{g}^{2}}{b_{g}^{2}+b_{e}^{2}}$, where Variety variance $=b_{g}^{2}+b_{\epsilon}^{2}$, and Error
variance $=b_{e}^{2}$. 
$F_{5}$ lines and $S$. almum, and also between the cultivated autotetraploid line A and $S$. almum. There can be no doubt about the origin of these natural crosses: they occurred in an out-of-season planting consisting of the cultivated tetraploid sorghums $A$ and $B$, derivatives of the cross $\mathrm{A} \times \mathrm{B}$, and $S$. almum. There were no other sorghums in the area, and there are no wild tetraploid sorghums in Uganda. In every case the cultivated autotetraploid was the female parent, and there is no possibility of confusion between an $F_{1}$ of (cultivated sorghum $\times S$. almum) and any natural intercrosses which might have occurred among the $\mathrm{A} \times \mathrm{B}$ material.

The inheritance of percentage seed-set in these crosses is shown in text-fig. I. The generations were not all grown simultaneously, but seasonal variation in seed-set is insufficient to mask the main effects. The data from line A are old, but this variety, developed in the dry climate of Ukiriguru, was not suited to the humid Serere climate, at either diploid or tetraploid levels.

The seed-set figures from the cross between line A and S. almum in text-fig. I show at least partial dominance of the high seed-set of S. almum, and segregation evidently occurred in the $\mathrm{F}_{2}$ generation. The long tail of low seed-set plants corresponding to the line A parent is clearly seen.

For the cross between the $\mathrm{F}_{5}$ selected lines of $(\mathrm{A} \times \mathrm{B})$ and $S$. almum in text-fig. I, data from the $F_{6}$ derivatives of all $I_{3}$ lines which took part in the original crosses have been combined to give the parental distribution of seed-set. There is a marked peak in the 74-75.9 per cent. seed-set class, and although there are 3 plants in the classes 40-54 per cent., there is no real low seed-set tail. At the upper end, there are 3 plants in the 86-9I $\cdot 9$ per cent. classes, but nothing in the classes $92-97 \cdot 9$ per cent., which is where the main peak of the $S$. almum bulk occurs. The $S$. almum bulk was grown simultaneously with the $\mathrm{F}_{6}$ of the $(\mathrm{A} \times \mathrm{B})$ parent lines.

The $F_{1}$ generations of both crosses were grown simultaneously, and their distribution is rather similar, except that the second cross has two plants in class $50-5 \mathrm{I} \cdot 9$ per cent. The upper limit of the seed-set is the $90-9 \mathrm{I} \cdot 9$ per cent. class in both cases. The data for the second cross $\mathrm{F}_{1}$ are combined from all the $\mathrm{F}_{1}$ plants from the $\left[(\mathrm{A} \times \mathrm{B}) \mathrm{F}_{5} \times S\right.$. almum] crosses.

The two $\mathrm{F}_{2}$ generations were grown simultaneously, but that for the $\left[(\mathrm{A} \times \mathrm{B}) \mathrm{F}_{5} \times S\right.$. almum $]$ cross in text-fig. I is from the deliberate crosses only, the natural crosses were not followed in detail to the $F_{2}$. The contrast between the two $F_{2}$ generations is striking. The upper limits are much the same, there being a few plants of both with seedsets above 92 per cent. The lower limits are very different. Whereas in the cross (line $\mathrm{A} \times S$. almum) $\mathrm{F}_{2}$ there is the long tail of low seed-set classes, in the cross $\left[(\mathrm{A} \times \mathrm{B}) \mathrm{F}_{5} \times S\right.$. almum] there are no plants with seed-sets below 48 per cent. It was earlier presumed that selection in the $(\mathrm{A} \times \mathrm{B})$ cross had resulted in the rapid elimination of the low 

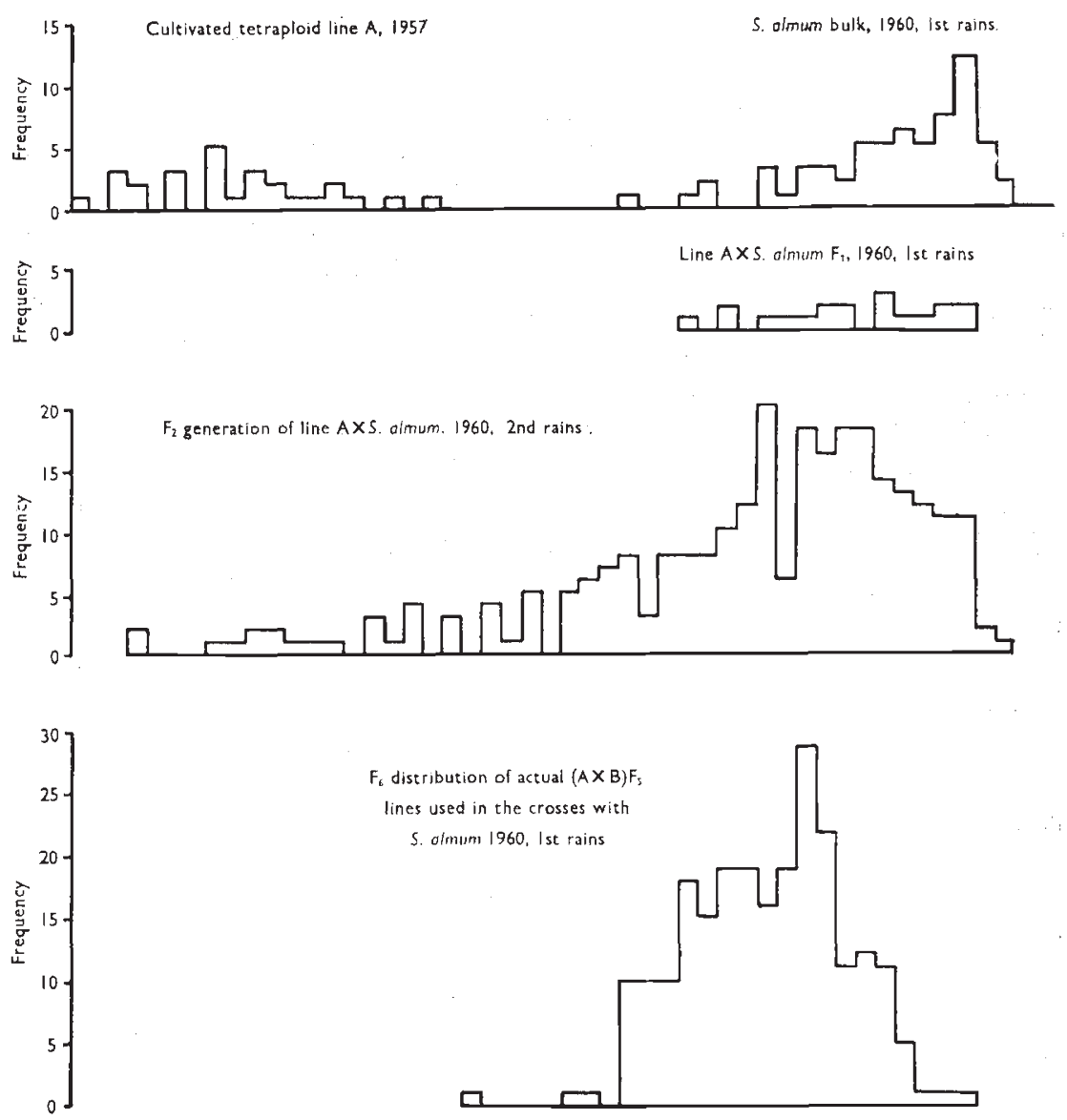

$\left[(A \times B) F_{3}\right.$ lines S. almum $\mid F_{1}, 1960$, ist rains
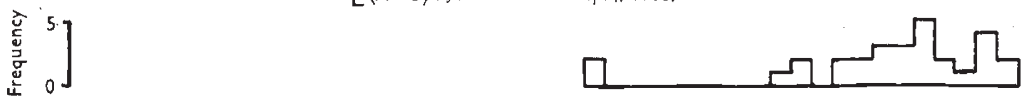

$F_{2}$ generation of $(A \times B) F_{5}$ lines crossed with S. almum, 1960, 2nd rains

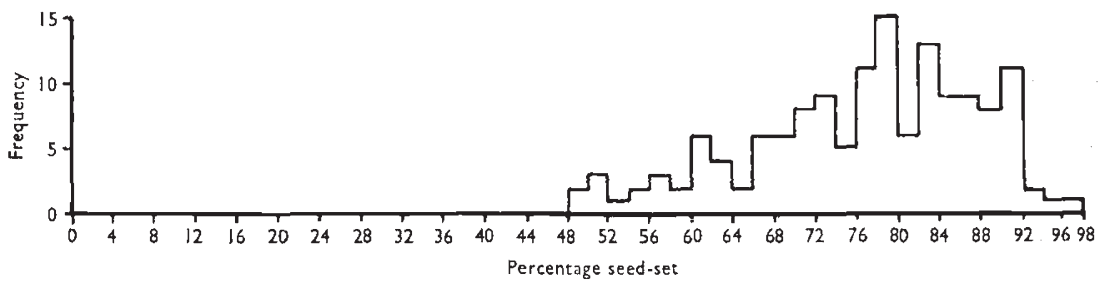

TexT-FIG. I.-The inheritance of seed-set in a cross between cultivated autotetraploid sorghum line $A$ and Sorghum almum and in a cross between $F_{5}$ lines from the tetraploid hybrid $\mathrm{A} \times \mathrm{B}$ and $S$. almum.

seed-set classes (Doggett, 1964 ). This selection was begun in the $F_{3}$, and it is evident from text-fig. I here that the low seed-set classes had been eliminated by the $F_{5}$. The conclusions of the earlier paper are thus confirmed. 
(iii) Selection within S. almum

Detailed data were not collected during the early stages of selection for high fertility in S. almum. Selections behaved as would be expected of a dominant character. High seed-set selections showed much

TABLE 2

Seed-set in selfed and selected S. almum lines $(1963)$

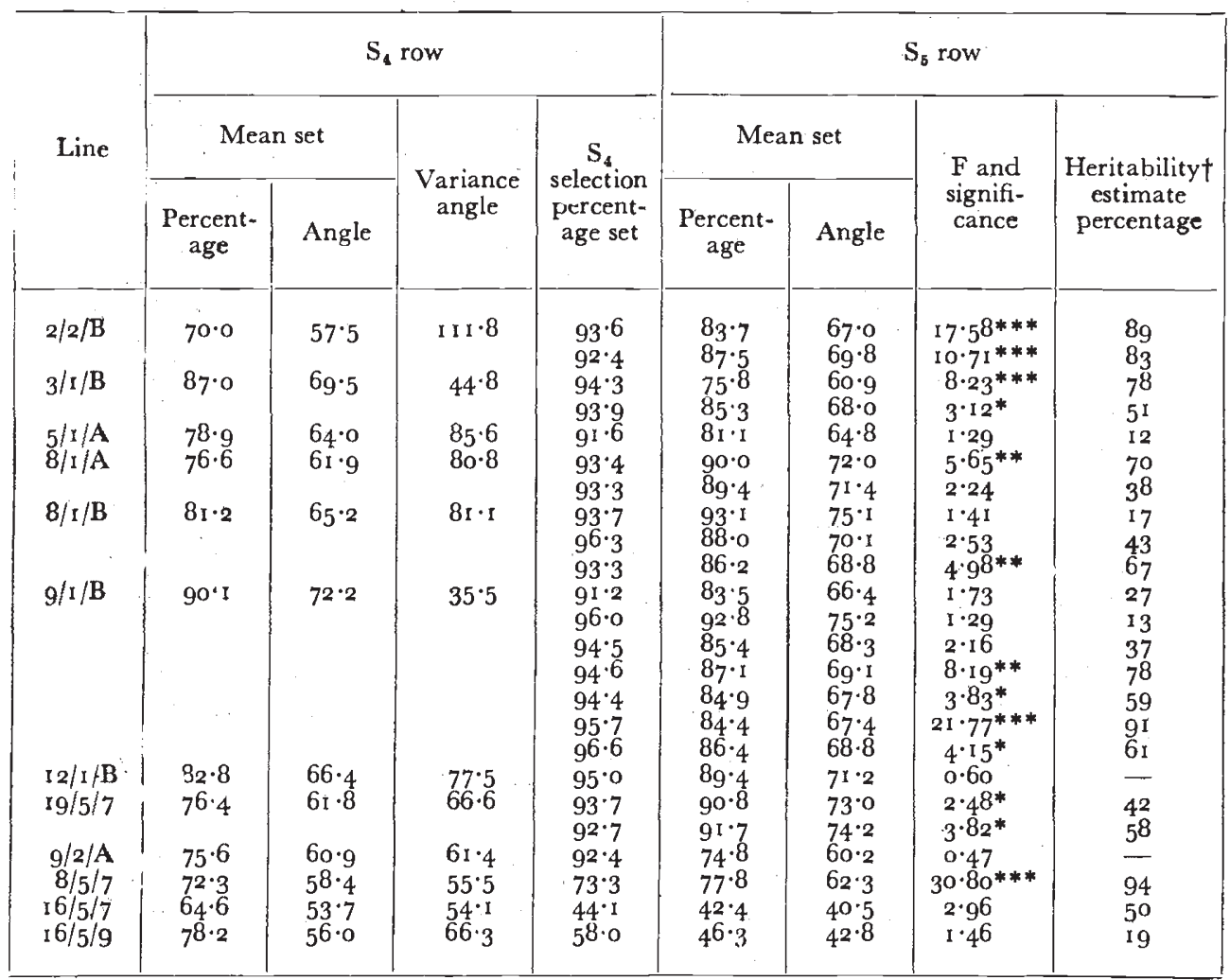

† Heritability calculated from $h^{2}=\frac{\sigma_{e}^{2}}{\sigma_{e}^{2}+\sigma_{G}^{2}}$, on the assumption that within plant variance $=\sigma_{e}^{2}$, and between plant variance $=b_{e}^{2}+2 \sigma_{G}^{2}$.

These $h^{2}$ estimates may be slightly high, as they assume the non-heritable variance between plants is no greater than that within plants. All the data on replicated seed-set counts at Serere indicate that this assumption, though perhaps unexpected, is a reasonable approximation.

segregation, and low seed-set plants often appeared. Low seed-set selections showed some segregation, but never produced high seed-set plants. Counts were made in the $\mathrm{S}_{4}$ generation. Mean seed-sets of 34 progeny rows analysed varied from go to 59 per cent., and variances ranged from 8.7 ( 7 plants) to i I0.9 (6 plants). No really low seed-set rows were included in these counts. In the corresponding $S_{5}$ generation, it was pessihle to count 2 tillers on each plant in a number of the 
progeny rows, which allowed an estimate of the within-plant and between-plant variances. These gave some idea of the heterogeneity still in the rows, and enabled estimates of heritability to be made. The data for this $S_{5}$ generation, together with the relevant figures from the corresponding $\mathrm{S}_{4}$ rows and selections, are shown in table 2.

From the last two columns of table 2, it is evident that a lot of genetic variance remains in many of the lines. Even the low seed-set lines $16 / 5 / 7$ and $16 / 5 / 9$ appear to retain some variability, though the $F$ tests were not significant. The $F$ value for the medium seed-set row $8 / 5 / 7$ is highest of all, and this is not surprising, as rows with 70 to 80 per cent. seed-set could well be very heterozygous. Two of the high seed-set lines in $2 / 2 / B$, and one in $9 / 1 / B$, are also very heterozygous.

It is too early to be sure how the very high seed-set levels behave on inbreeding and selection. 9/I/B looked most promising in $\mathrm{S}_{4}$, with a row mean of $90^{\circ} \mathrm{I}$ per cent., but only one of its rows gave a mean set over 90 per cent. in the $S_{5}$. 8/1/B shows one promising $S_{5}$ row with a mean of $93^{\circ}$ I per cent., and a good measure of homozygosity. I $19 / 5 / 7$ was evidently still quite heterozygous in the $\mathrm{F}_{4}$, and gave 2 promising rows in $F_{5}$. It may prove difficult to obtain a stable seed-set much above 90 per cent. from this material, but such a level would be sufficient for practical purposes. There is no reason to suppose that this selection programme has exhausted the potential of the $S$. almum population, and still higher fertility levels could doubtless be obtained from it.

Using all the data from the $\mathrm{S}_{5}$ generation, which includes those plants which did not produce 2 tillers for counting, the regression of $S_{5}$ row on the $\mathrm{S}_{4}$ selection from which it was derived is $b=0.82 \mathrm{I} \pm 0.057$. This is again a high estimate of heritability, which is statistically significant with a $t$ value of 14 for $n=33$.

It is clear from this section that Sorghum almum contains genotypes which give fertility levels little different from those of diploid sorghum, and which are highly heritable.

\section{THE TRANSFER OF HIGH SEED-SET FROM S. ALMUM TO AUTOTETRAPLOID CULTIVATED SORGHUMS}

\section{(i) First backcross}

Forty selections were taken from the $\mathrm{F}_{2}$ generation of $\left[\left(\mathrm{A} \times \mathrm{B} \mathrm{F}_{5}\right.\right.$ $\times S$. almum] (see text-fig. I). Seed-sets in the $\mathrm{F}_{3}$ generation from these selections were counted on 15 plants in each row. Of the row seed-set means 39 were 70 per cent. or above, while 16 of these were 80 per cent. or above. The regression of progeny row on parental head was $b=0 \cdot 29 \mathrm{I} \pm 0 \cdot 167$, which is not significant at $P=0 \cdot 05$. The segregation of seed-set using the individual $\mathrm{F}_{3}$ plants is illustrated in text-fig. 2 . All $40 \mathrm{~F}_{2}$ selections should have been carrying dominant genes for high fertility, and the $\mathrm{F}_{3}$ histogram in text-fig. 2 is consistent with this theory. A series of backcrosses was made from these $F_{3}$ lines on to two cultivated 
autotetraploid sorghums, $\mathrm{T}_{42} \mathrm{~B}$ and Tmgl. Both varieties were derived from the same breeding programme which had yielded the original line $\mathrm{A}$ and line $\mathrm{B}$. Both are much more robust plants than lines $A$ and $B$. In the season when the backcrosses were made, $T_{42} B$ had a mean seed-set of 54 per cent. (range $29-78$ per cent., 72 plants counted) and Tmgl a mean of 44 per cent. (range 2I-72 per cent., 37 plants counted).

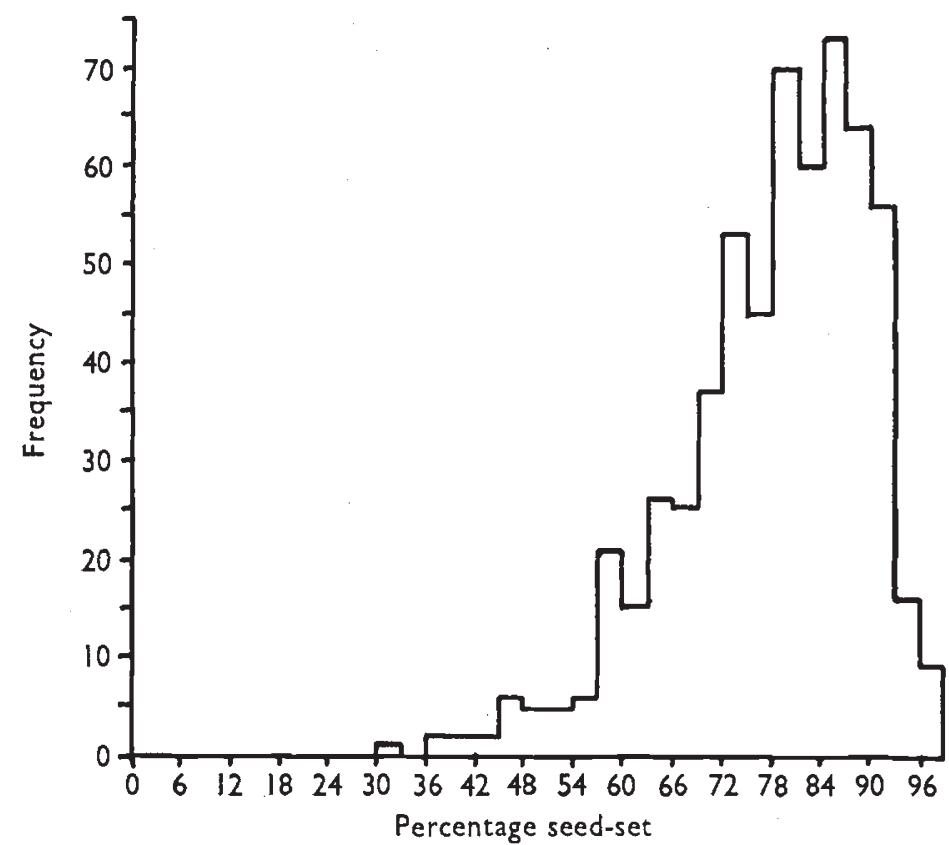

TEXT-FIG. 2.- Segregation of seed-set in the $F_{B}$ generation of the sorghum cross [cultivated autotetraploid $(\mathrm{A} \times \mathrm{B}) \mathrm{F}_{\mathrm{B}} \times S$. almum]. The $40 \mathrm{~F}_{2}$ heads from which this $\mathrm{F}_{3}$ was grown had been chosen for their high seed-set.

The $F_{1}$ generations grown from the $6_{4}$ backcrosses to $T_{42} \mathrm{~B}$ and Tmgl were selected for seed-set. Check counts made on 66 of the best plants showed that $\mathrm{I} 7$ had seed-sets of 95 per cent. or above, and 49 had seed-sets of 9o-94 per cent. The fertility of these first backcrosses was not followed in detail in subsequent generations. Most of the plants were wild type, and the material was rapidly thinned down to about 50 lines' possessing cultivated characters.

\section{(ii) The second backeross}

This backcross was made directly from the $F_{1}$ of the first backcross on to a wider range of cultivated types. In addition to $\mathrm{T}_{42} \mathrm{~B}$ and $\mathrm{Tmgl}$, there were 2 South African Kafir types (Natal Red and Pietersburg Baker), 3 very distinct Feteritas, 2 Durras and the U.S. combine-type Redlan. All these sorghums had previously been made tetraploid with colchicine. It was considered important to get as much as 

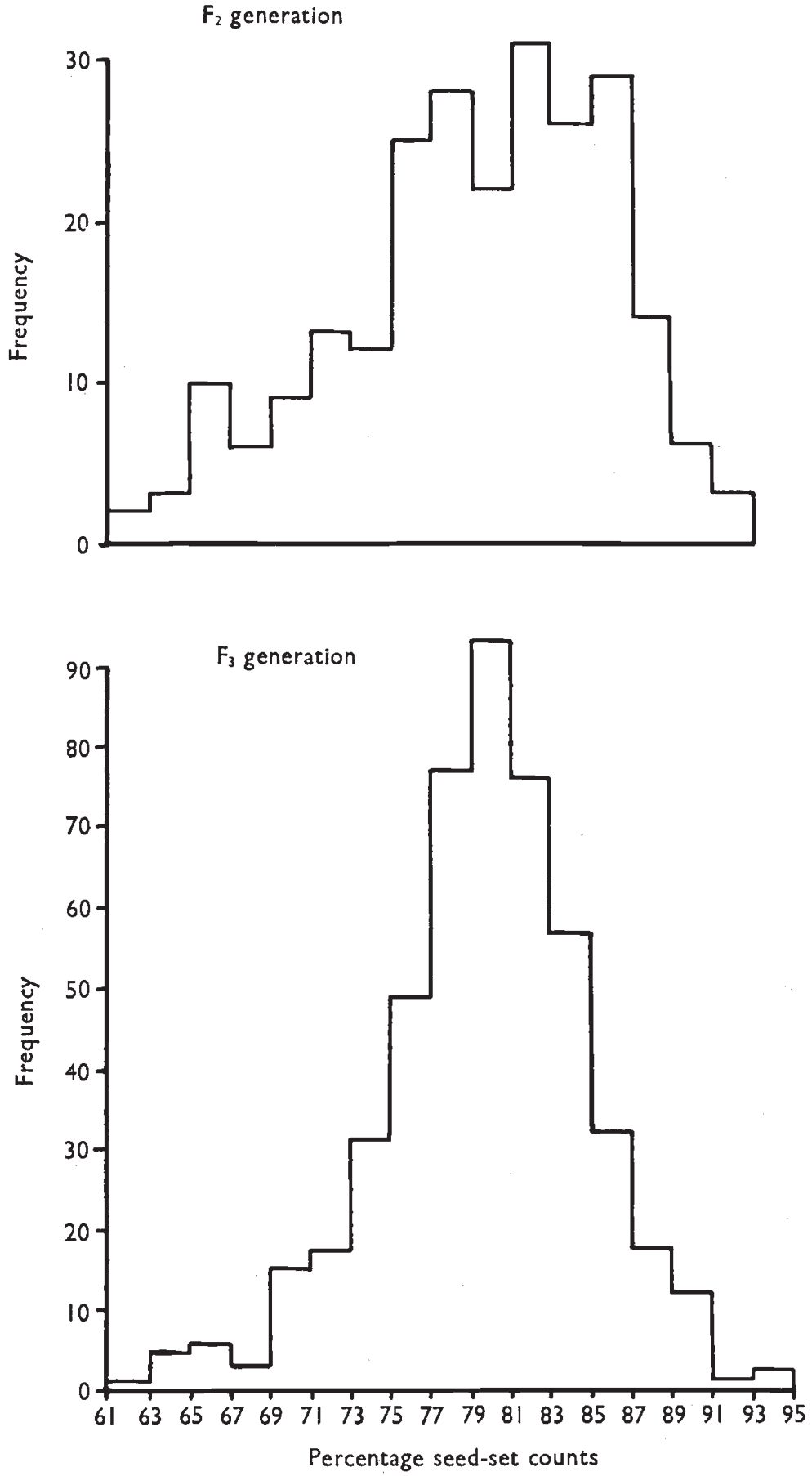

TeXT-FIG. 3.-Check seed-set counts on $F_{2}$ and $F_{3}$ generations of the second backcross of cultivated autotetraploid sorghum $\times S$. almum. 
possible of the diversity of the diploid sorghums into the tetraploid programme. Tetraploid sorghum hybrids are a major objective, and the high fertility of $S$. almum will be needed in both parents if the hybrids are to be grown for several generations without seed renewal.

Selection and counting of sample rows was continued in the $F_{2}$ and $F_{3}$ generations of this backcross, and the histograms in text-fig. 3 illustrate the distributions of seed-set found. Setting conditions were not ideal

TABLE 3

Seed-sets in second backcross families (percentages)

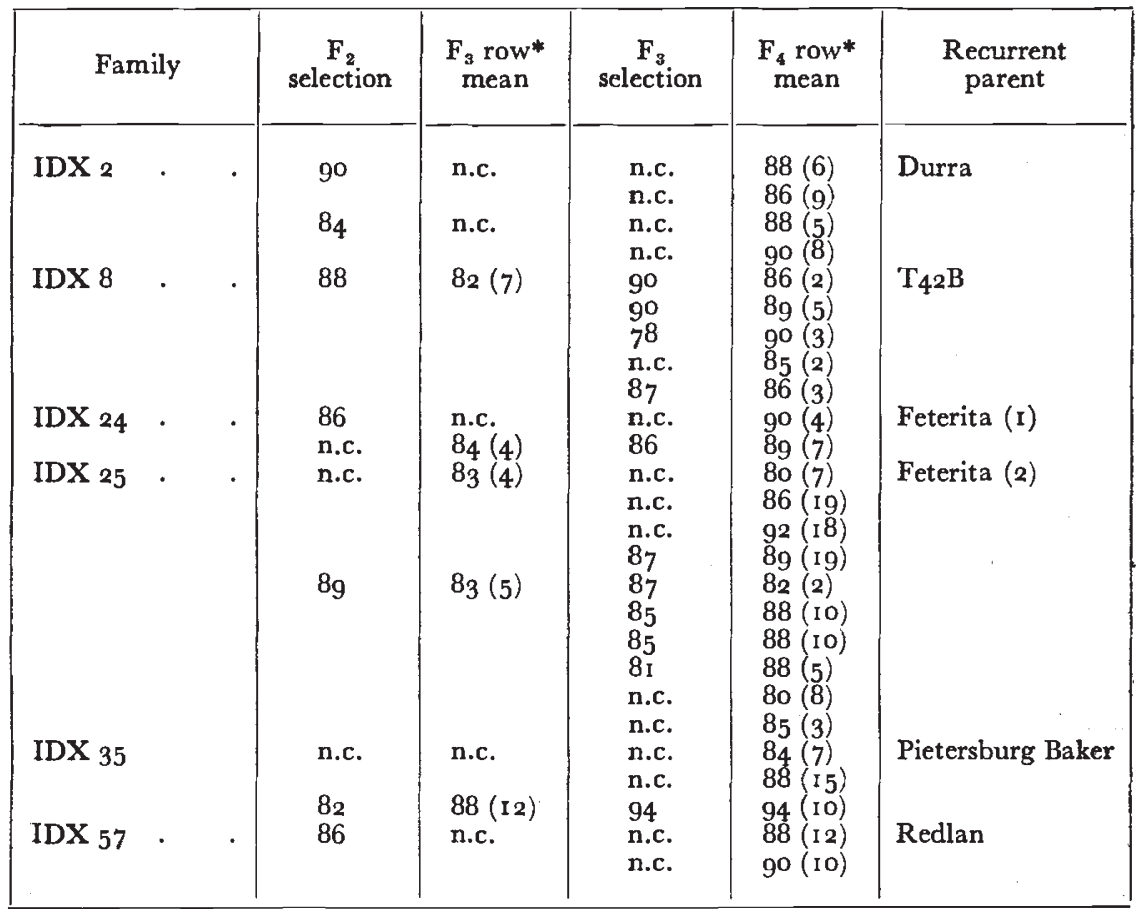

n.c. $=$ not counted.

* The number of plants counted for each mean is shown in brackets.

for either generation, there was some midge damage and some trouble from Sphacelia sorghi. The regression of $\mathrm{F}_{3}$ row on $\mathrm{F}_{2}$ selected head from which it came was $b=0 \cdot 1 \mathrm{I} 8 \pm 0 \cdot 064$, which is significant between the $\mathbf{P}=0.05$ and $\mathbf{P}=0.1$ levels.

Six of these second backcross groups gave promising mean seed-sets in the progeny rows of the $\mathrm{F}_{4}$ generation, and a summary of their behaviour is given in table 3 . The regression of $\mathrm{F}_{4}$ row on $\mathrm{F}_{3}$ selection for all the data was $b=0 \cdot 192 \pm 0.121$ which with roo degrees of freedom does not reach significance even at $P=0 \cdot I$. Taking just the high seed-set lines, the regression value is very low, $b=0 \cdot 0 \mathrm{I} 3 \pm 0 \cdot 180$. It thus seems that genetic variance for seed-set in the lines selected for 
high fertility had reached a very low level by the $F_{4}$. The corresponding covariances from these figures are $\mathrm{I} \cdot 88$ and $0 \cdot 28$.

IDX 35 is very satisfactory in table 3 . This family possesses Shallu characters of grain and glume, which were present on both sides of the first backcross, and has produced some presentable cultivated sorghums (plate I). IDX 25 is also a promising family, and data were collected on the fertility of the $F_{5}$ generation in one of its sub-families as shown in table 4 .

Pollen mother cells in all the most fertile lines of families IDX 25 and IDX 35 have been checked, and all were tetraploid with $4^{x}=4^{\circ}$ chromosomes. No diploid plant has yet arisen in either family.

The similarity between the data in tables 3 and 4 and that in the S. almum data in table 2 is evident. High seed-set has been moved across successfully from $S$. almum to cultivated autotetraploid sorghum as far

TABLE 4

Seed-sets in the $F_{5}$ generation of part of family IDX 25 (second backcross) (percentages)

\begin{tabular}{|c|c|c|c|c|c|c|c|}
\hline $\begin{array}{c}F_{4} \\
\text { selection }\end{array}$ & $\begin{array}{c}F_{5} \\
\text { mean }\end{array}$ & $\begin{array}{c}\text { No. of } \\
\text { plants } \\
\text { counted }\end{array}$ & Range & $\begin{array}{c}F_{4} \\
\text { selection }\end{array}$ & $\begin{array}{c}F_{5} \\
\text { mean }\end{array}$ & $\begin{array}{c}\text { No. of } \\
\text { plants } \\
\text { counted }\end{array}$ & Range \\
\hline & & & & & & \\
\hline $90 \cdot 7$ & $87 \cdot 7$ & 17 & $82 \cdot 8-96 \cdot 5$ & $92 \cdot 9$ & $88 \cdot 4$ & 16 & $77 \cdot 3-92 \cdot 4$ \\
$86 \cdot 4$ & $86 \cdot 0$ & 14 & $79 \cdot 6-91 \cdot 9$ & $89 \cdot 3$ & $87 \cdot 4$ & 19 & $76 \cdot 8 \cdot 92 \cdot 9$ \\
$90 \cdot 1$ & $88 \cdot 8$ & 15 & $80 \cdot 5 \cdot 93 \cdot 8$ & $90 \cdot 6$ & $86 \cdot 6$ & 14 & $71 \cdot 5 \cdot 92 \cdot 4$ \\
$95 \cdot 2$ & $87 \cdot 9$ & 20 & $75 \cdot 4 \cdot 95 \cdot 5$ & $92 \cdot 0$ & $87 \cdot 4$ & 18 & $79 \cdot 6 \cdot 92 \cdot 2$ \\
\hline
\end{tabular}

as the second backcross. Further, there is no sign of any tight linkages between the high seed-set genes and wild or undesirable characters. Selection in the backcrossing programme for cultivated characters has been sustained at a high level, and cultivated type plants with high seed-set have been obtained. Fertility levels not very different from those of diploid sorghum are present in this second backcross material.

\section{(iii) Third backcross and subsequent crosses}

The third backcross was made from the $\mathrm{F}_{2}$ and $\mathrm{F}_{3}$ generations of the second backcross. Once successful transmission of high seed-set had been demonstrated, there was no purpose in continuing detailed counts in the later backcrosses, and no data are offered here. The programme became one of orthodox plant breeding. Most cultivated characters in sorghum are recessive, and handling such characters at the tetraploid level will require quite a lot of backcrossing. It will be necessary to ensure at intervals that the full fertility level is being maintained, and this is now being done in the second backcross. When more is known of the $S$. almum genotypic control of seed-set, a further cycle of crosses from improved $S$. almum may be desirable. 


\section{INTERFERENCE}

Cultivated sorghum has the advantage of being 90-95 per cent. self-pollinated under most environmental conditions. It was clear from the trial in table I that interference was not an important factor in reducing seed-sets, though it may well have had some effect. $S$. almum pollen is readily distributed, and natural crosses appear frequently in cultivated autotetraploids if there is any S. almum in the same field. In the breeding work, no attempt has been made to isolate the tetraploid from the diploid part of the programme. All the data reported here have been obtained on material growing in juxtaposition to diploid sorghum, with large quantities of diploid pollen being shed freely in the same fields. There is no reason to fear the elimination of tetraploid sorghums through diploid pollen in normal material, as was found in tetraploid maize by Cavanah and Alexander (1963). Male sterile plantings may present more difficulty, but the pollination of these is in any case always carefully controlled.

\section{THE CAUSES OF HIGH SEED-SET \\ (i) Alloploid effects}

It seems clear from the foregoing data that the high seed-set of S. almum and its derivatives cannot be due to preferential pairing

TABLE 5

Seed-sets in derivatives of a polyhaploid plant (percentages) from the second backcross of (autotetraploid grain sorghum $\times \mathrm{S}$. almum)

\begin{tabular}{|c|c|c|c|}
\hline $\mathrm{S}_{1}$ row mean & $\mathrm{S}_{1}$ selection & $\mathrm{S}_{2}$ row mean & $\mathrm{S}_{2}$ range \\
\hline $\begin{array}{l}86 \cdot 3 \\
S_{1} \text { range } \\
79 \cdot I-9^{2} \cdot 9\end{array}$ & $\begin{array}{l}88 \cdot 2 \\
87 \cdot 0 \\
\text { n.c. } \\
\text { n.c. } \\
82 \cdot 7 \\
84 \cdot 2\end{array}$ & $\begin{array}{l}76 \cdot 6 \\
89 \cdot 8 \\
87 \cdot 5 \\
89 \cdot 4 \\
92 \cdot 5 \\
87 \cdot 5\end{array}$ & $\begin{array}{l}55 \cdot 5-86 \cdot 2 \\
79 \cdot 8-94 \cdot 0 \\
83 \cdot 6-90 \cdot 3 \\
83 \cdot 2-94 \cdot 8 \\
87 \cdot 3-94 \cdot 5 \\
82 \cdot 5-91 \cdot 3\end{array}$ \\
\hline
\end{tabular}

n.c. $=$ not counted.

through chromosome differentiation. Neither classical alloploidy nor segmental alloploidy seems to be involved here. Polyhaploids provide formal proof of this. The original Mgl cultivated line was derived from a haploid plant which set 7 diploid seeds when open-pollinated. Four of these seeds were doubled with colchicine to give Tmgl, and the remaining 3 gave the diploid $\mathrm{Mgl}$ line. A search for haploids has not been made in the latter. However, the tetraploid Tmgl transmits to its offspring a tendency to halve the chromosome number, and occasional polyhaploids appear in the families derived from it. This has conveniently occurred in the second and third backcrosses. The fertility of the progeny from one polyhaploid plant which arose in the second 
backcross is shown in table 5 , and text-fig. 4. This polyhaploid plant showed a seed-set of $96 \cdot 3$ per cent. One which appeared in the $F_{1}$ of the third backcross had a seed-set of $97^{\circ} \cdot 2$ per cent. To obtain these high values, chromosome pairing in the polyhaploids must have been complete, and there can have been no large differences between the chromosomes.
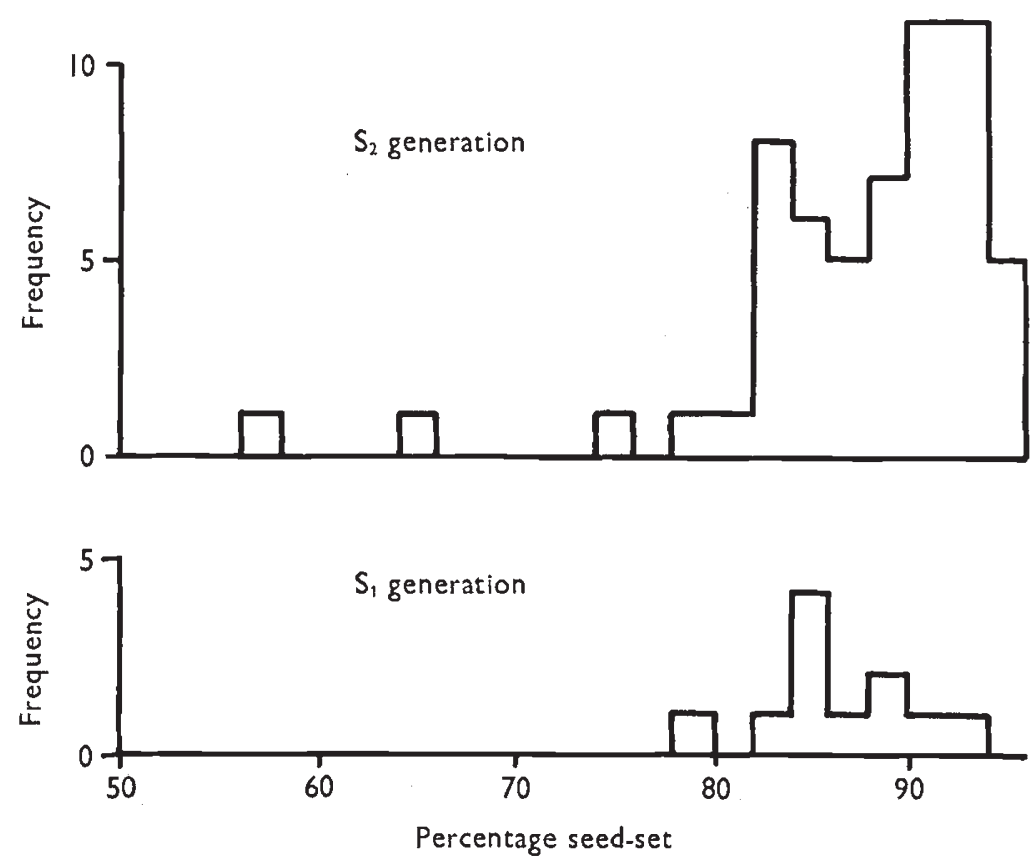

TEXT-FIG. 4.-Segregation for seed-set in a polyhaploid sorghum from the second backcross of (autotetraploid grain sorghum $\times S$. almum).

These data, though sparse, show that the polyhaploid is also segregating for seed-set, and confirm that we are dealing with genotypic control of fertility.

\section{(ii) Diploidisation}

Detailed cytological studies are outside the scope of the present paper, but the few data in table 6 are sufficient to establish that complete diploidisation has not occurred.

For the two $S$. almum plants in table 6, the seed-sets of the actual plants examined are known. Although the high seed-set plant of $9 / \mathrm{I} / \mathrm{B}$ has more bivalents than the low seed-set plant of $16 / 5 / 7$, the difference is small, and probably not related to the seed-set differences. Many more $S$. almum lines would need to be examined to establish this. However, the two second backcross derivatives have fewer bivalents than I6/5/7 P.I3, and yet their seed-sets must have been higher, judging from the row means and ranges. It seems that diploidisation cannot have been responsible for the improved seed-set. Endrizzi 
(1957) obtained average figures for S. almum of 0.32 I, I I 52 II, o 08 III and $4^{\circ}$ Io IV. It will be seen that the two backcross lines in table 6 approximate more closely to Endrizzi's figures than do the $S$. almum lines. The differences are not very great, however, and natural variation within S. almum could well account for them. Celarier (I958) reported means of $0.54 \mathrm{I}$, I6.70 II, $0.06 \mathrm{III}, \mathrm{I} \cdot 45 \mathrm{IV}$ and $0.0 \mathrm{I}$ VI, but

TABLE 6

Chromosome configurations in $\mathrm{S}$. almum and in the second backcross to cultivated sorghum. (Counts made at late diakinesis or metaphase I, 25 cells analysed per plant)

\begin{tabular}{|c|c|c|c|c|c|c|c|c|c|}
\hline \multirow{2}{*}{ Variety } & \multirow{2}{*}{$\begin{array}{l}\text { Seed set of } \\
\text { plant } \\
\text { (2 tillers) }\end{array}$} & \multirow{2}{*}{$\begin{array}{l}\text { Seed set of } \\
\text { row* } \\
\text { (percentage) }\end{array}$} & \multirow{2}{*}{$\begin{array}{l}\text { Range of } \\
\text { seed set } \\
\text { in row } \\
\text { (percentage) }\end{array}$} & \multicolumn{4}{|c|}{ Configurations per cell } & \multicolumn{2}{|c|}{$\begin{array}{l}\text { No. of bivalents } \\
\text { per cell }\end{array}$} \\
\hline & & & & I & II & III & IV & Highest & Lowest \\
\hline $\begin{array}{l}\text { Almum } \\
16 / 5 / 7 \text { P.13 }\end{array}$ & $\begin{array}{l}43^{\circ} 0 \\
4^{\circ} \cdot 4\end{array}$ & $42 \cdot 4(21)$ & $25 \cdot 4-5^{6 \cdot 8}$ & - & 13.04 & - & $3 \cdot 4^{8}$ & 18 & 10 \\
\hline $\begin{array}{l}\text { Almum } \\
\text { 9/1/B P.4 }\end{array}$ & $\begin{array}{l}93 \cdot 5 \\
91 \cdot 4\end{array}$ & $84 \cdot 9$ (25) & $64 \cdot 3-95 \cdot 1$ & 0.08 & $14 \cdot 44$ & - & $2 \cdot 76$ & 18 & 10 \\
\hline $\operatorname{IDX} 25 / \mathrm{A} / 8 / 3$ & - & $91 \cdot 6(18)$ & $83 \cdot 8-97 \cdot 8$ & - & $11 \cdot 44$ & - & $4 \cdot 28$ & 14 & 8 \\
\hline $\operatorname{IDX}_{35 / A} / 3 / 1$ & - & $94 \cdot 5(10)$ & $90 \cdot 1-98 \cdot 2$ & - & $11 \cdot 12$ & - & $4 \cdot 44$ & 14 & 8 \\
\hline
\end{tabular}

* The number of plants counted for the mean is in brackets.

he noted that $S$. almum showed much more cytological variation between accessions than the other Halepensia studied. A metaphase plate of IDX 25 showing the presence of quadrivalents is illustrated in plate II.

\section{DISCUSSION}

Lines of high and low fertility have been extracted from a Sorghum almum population. A cross between low seed-set autotetraploid cultivated sorghum and $S$. almum showed partial dominance of the S. almum fertility level, and plants with high and low fertility levels were recovered in the $F_{2}$. When autotetraploid cultivated sorghum of medium seed-set was crossed with $S$. almum, no low seed-set plants appeared in the $F_{2}$. The high seed-set of $S$. almum has been transferred to autotetraploid cultivated sorghum. Evidently high fertility in S. almum is genotypically controlled.

It seems unlikely that many major genes are involved in the difference between high and low seed-set. The inheritance is apparently fairly simple in text-fig. I, and selection for high seed-set reduced the genetic variance very rapidly in the crosses as shown by the covariance estimates from the $F_{3}$ and $F_{4}$ of the second backcross between cultivated sorghum and $S$. almum. However, the $S_{5}$ of the $S$. almum selections shows this effect to a lesser extent, for in more than 
half the $\mathrm{S}_{5} S$. almum lines in table 2 a significant level of genetic variance remains. The direct comparison is difficult to make. The $h^{2}$ estimates in table 2 may be inflated, although the regression value for the whole range of $S$. almum data was high $(b=0.82 \mathrm{I} \pm 0.057)$. However, it is quite possible that the $S$. almum inbreds in $\mathrm{S}_{5}$ have more genetic variance than the $F_{4}$ of the second backcross. In the latter, one or few genes from $S$. almum have been moved into a uniform cultivated background, obtained from doubling long inbred diploids. The $S$. almum is a very heterogeneous tetraploid population, and the extraction of homozygous lines with a uniform modifier background must be slow.

The $S$. almum population used here was heterogeneous for these high fertility genes, and their origin is probably to be traced to the origin of $S$. almum itself. Parodi (1943) from morphological and cytological data concluded that $S$. almum had arisen from a cross between one of the diploid Arundinacea forage sorghums and S. halepense, through the functioning of an unreduced gamete on the former. $\mathrm{He}$ thought that $S$. almum arose at some time before I933. Clearly it cannot be ancient, as $S$. halepense itself did not reach the New World until I 830 when it was imported into California (Martin and Leonard, 1949). Endrizzi (1957) from cytological studies thought that a grain sorghum was the more probable Arundinacea parent of $S$. almum, but otherwise confirmed Parodi's theory of its origin.

Sorghum halepense is an ancient tetraploid. Some workers consider it an autotetraploid, but most regard it as a segmental allotetraploid (Endrizzi, 1957). It could well have accumulated genes giving high fertility. Only one report of the fertility of $S$. halepense has been found. Raman and Krishnaswamy (1955) record it as having 95 per cent. stainable pollen. However, we can deduce that it must show good seed-set from the following considerations:-

I. None of the papers dealing with $S$. halepense comments on its seed-set, which would have attracted attention if evidently low. Karper and Chisholm (1936) report on chromosome numbers in sorghum. They mention hybrids between $S$. halepense and other sorghums, and state "All of the progeny examined showed the double number of 40 chromosomes, and, as would be expected from the balanced chromosome number, the plants were fertile and produced seed quite well". Some comment would certainly have been made on the $S$. halepense parent had it not shown a high seed-set. Similarly, there are several reports of the seed-sets of various hybrids between diploid, triploid, tetraploid sorghum and S. halepense (e.g. Endrizzi, r 957; Hadley, I953, 1958). The figures given vary from less than i per cent. to over 9o per cent. Nowhere is the fertility of the $S$. halepense parent mentioned, which must imply that the readers are expected to know that $S$. halepense is " fully" fertile.

2. Snowden (1955) made a comprehensive taxonomic study of wild fodder Eu-sorghums, and examined several hundred specimens of 


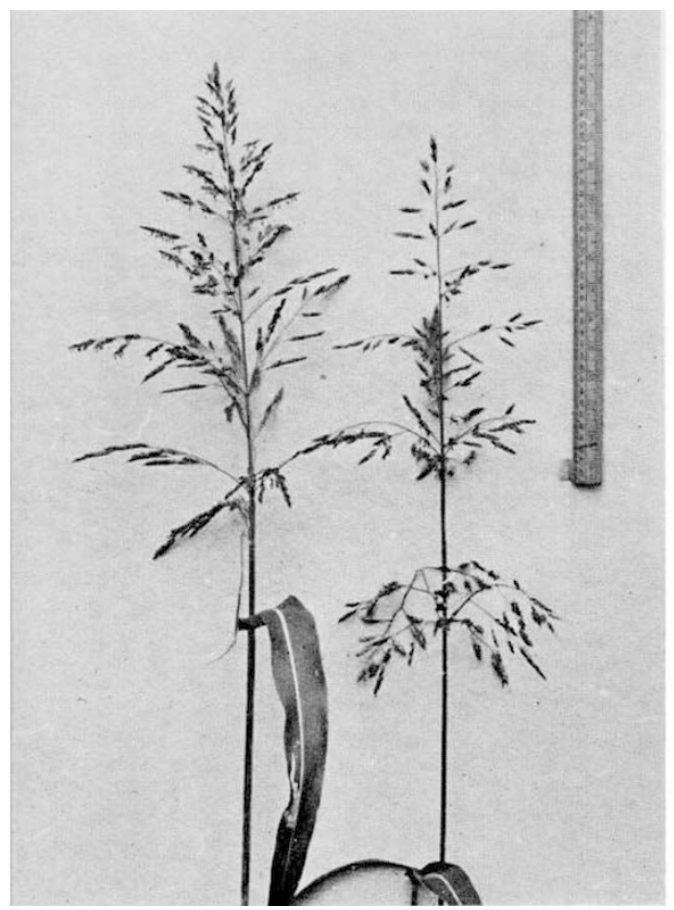

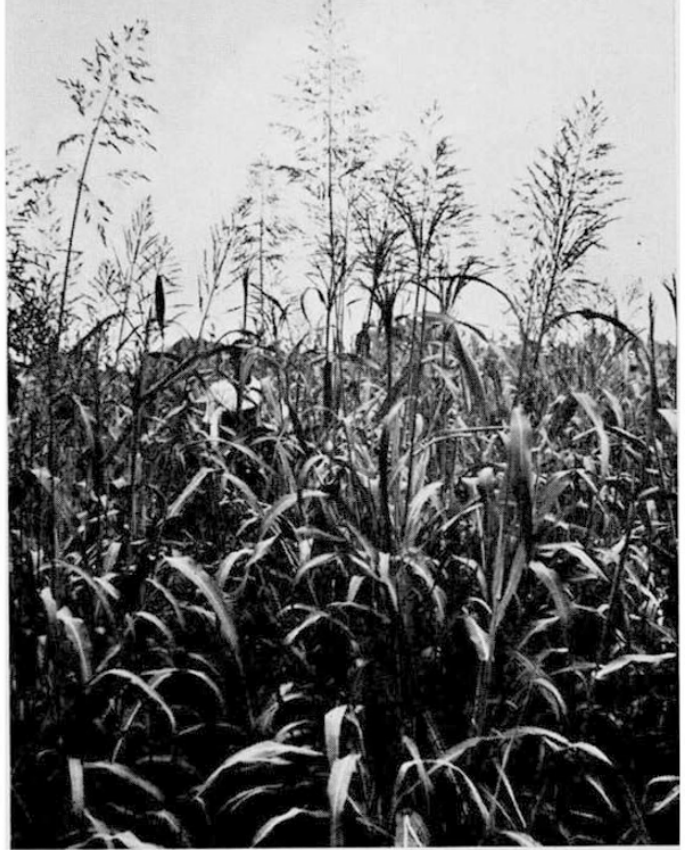

$B$

$A, B$. - Head and row of $S$. almum.

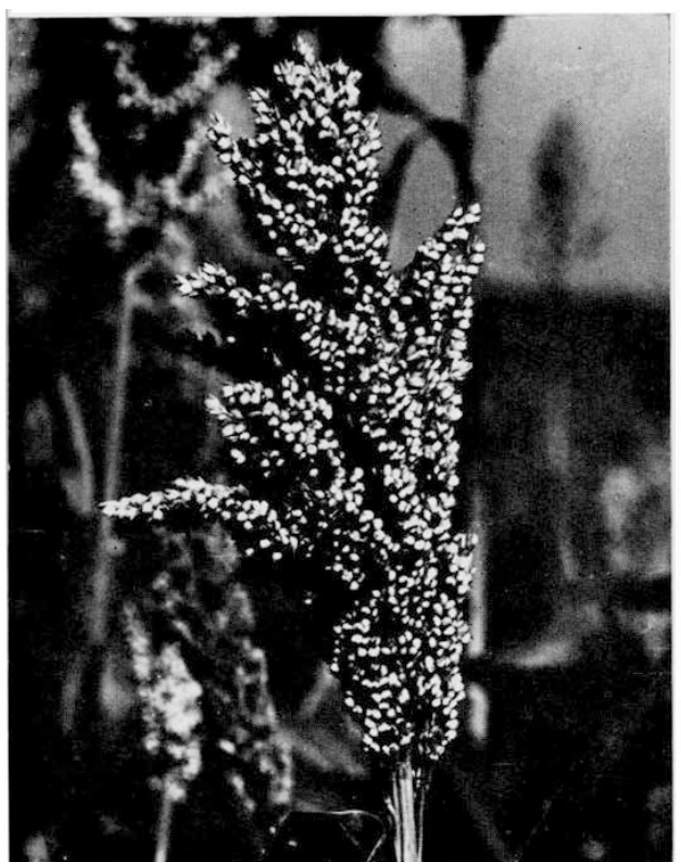

$C$

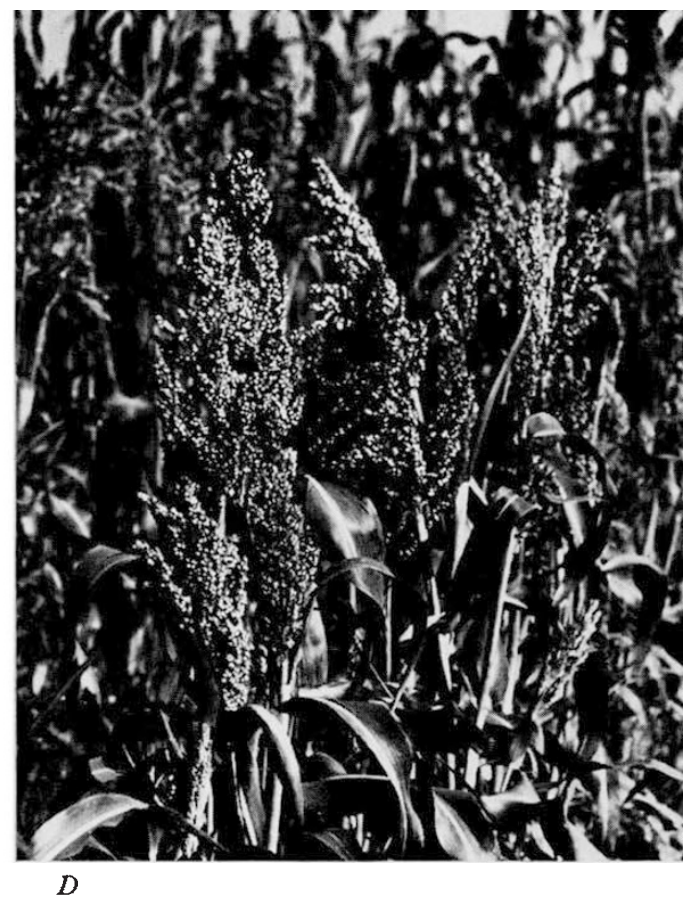

$C, D$. - Head and row of IDX 35 , a second backcross of cultivated tetraploid sorghum (recurrent parent) $\times S$. almum, with high seed-set. 
Plate II

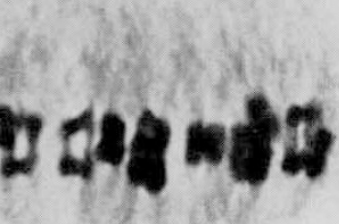

$2 \mathrm{~A}$
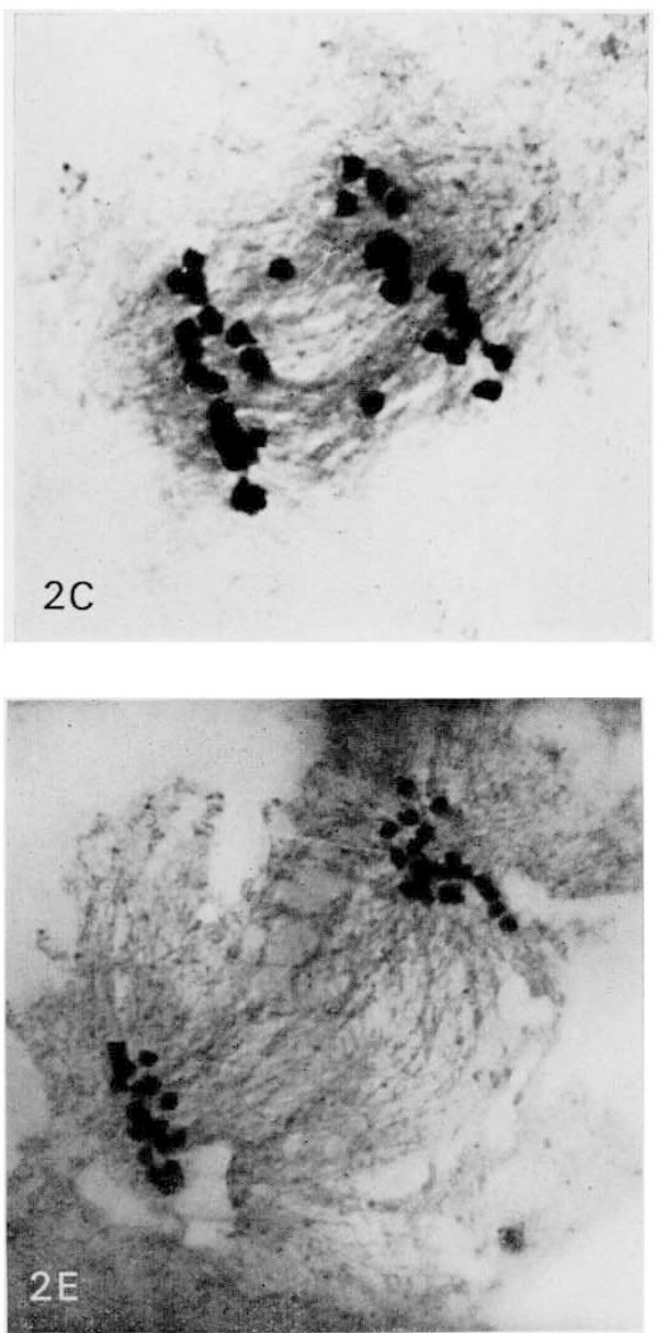
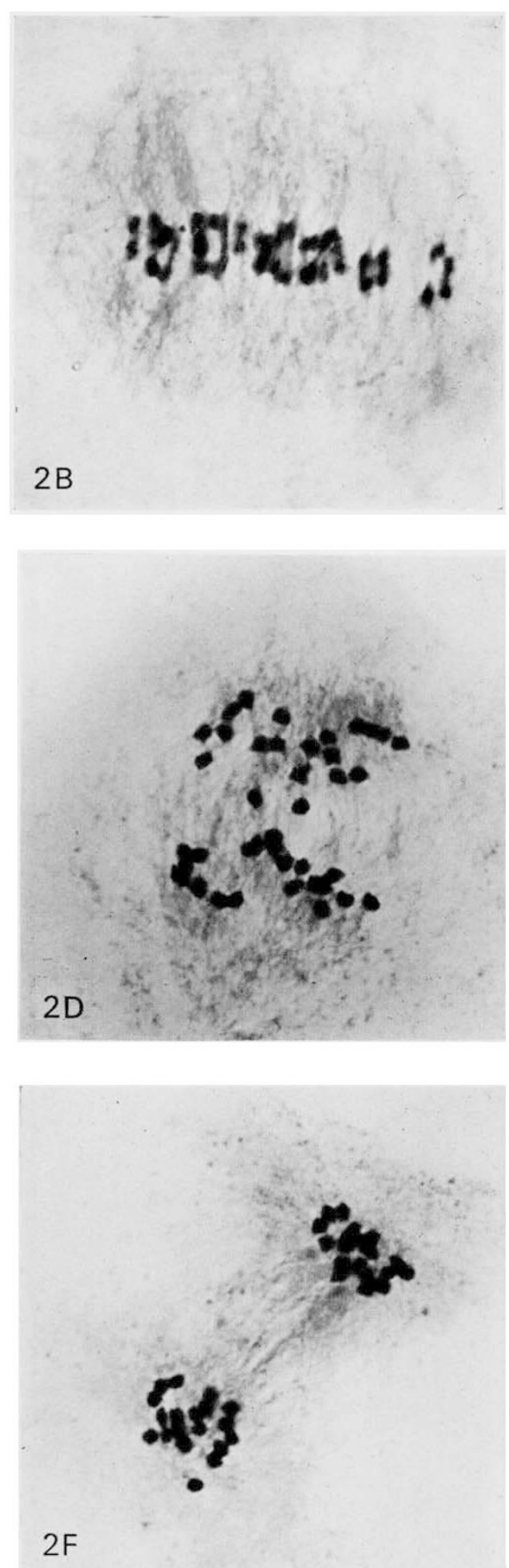

Chromosomes of IDX 25, from the second backcross of cultivated tetraploid sorghum (recurrent parent) $\times S$. almum.

$A, B$.- Metaphase I, showing presence of quadrivalents.

$C, D$.-Anaphase 1, with laggards remaining on the spindle. There are seldom more than 2 laggards.

$E, F$.-Normal anaphase $\mathrm{I}$. 
S. halepense and closely related types. A character such as reduced seedset would surely have been mentioned when comparisons were being made with the diploid Arundinacea sorghums.

A derivative from a cross between autotetraploid sorghum and S. halepense showed $80 \cdot 3$ per cent. seed-set (Casady and Anderson, 1952). Hadley (1958) reported $90 \cdot 1-98 \cdot 3$ per cent. of stainable pollen in 1o (male-sterile diploid sorghum $\times S$. halepense) hybrids, and seed-sets were estimated as over 75 per cent. These were all 40 chromosome plants. There is therefore good reason to presume both that $S$. halepense shows high fertility, and that this high seed-set can be inherited in crosses. The high fertility genes in $S$. almum were therefore almost certainly received from its $S$. halepense parent, and because $S$. almum is of recent origin, the population is still very heterozygous for these fertility genes.

The causes of high fertility are as yet uncertain, but it cannot be due either to preferential pairing through chromosome differences of the classical alloploid type (e.g. Stebbins, 1957) or to imposed complete diploidisation of the wheat type (Riley and Chapman, I958). Regular disjunction must be occurring to give such high seed-sets, and this seems to take place in $S$. halepense. Celarier (1958) in anaphase and telophase I recorded 20:20 distribution of the chromosomes, with no irregularities other than 16 per cent. of the cells showing laggards. A situation similar to this in the second backcross IDX 25 is shown in the anaphase I preparations of plate II. Laggards need not imply irregular chromosome distribution to the gametes. Endrizzi (1958) from a study of the orientation, types and frequencies of quadrivalents in $S$. almum and some almum crosses, suggested that directional segregation is a characteristic of this group of sorghums, the Eu-sorghums.

High fertility has already been transferred from $S$. halepense to $S$. almum, and is now being transferred to autotetraploid cultivated sorghum. There appears to be no barrier to the successful development of cultivated tetraploid sorghum as a grain crop.

\section{SUMMARY}

1. Selection in a population of Sorghum almum produced lines of high fertility, the seed-set levels being of a similar order to those of diploid grain sorghum.

2. High fertility was inherited in crosses between autotetraploid grain sorghum and $S$. almum. It proved to be dominant to low seed-set, which accords with the results previously obtained for medium fertility in tetraploid sorghum. The pattern did not seem very complicated, and it is unlikely that more than a few genes are involved.

3. High fertility has been successfully transferred from $S$. almum to autotetraploid grain sorghum as far as the second backcross. The high fertility genes are not tightly linked to undesirable wild characters.

4. The high fertility genes in this $S$. almum population were almost certainly derived from the $S$. halepense parent. 
5. High fertility is not due either to alloploid effects, or to complete diploidisation. It must involve regular disjunction.

6. There are no barriers to the development of tetraploid grain sorghum as a valuable crop plant.

Acknowledgments-I thank the E.A.A.F.R.O. Recorder Staff for the patient counting of many seed-sets, and am much indebted to D. Jowett for helpful discussion and reading of the manuscripts. S. Foye gave valuable help with the photography.

\section{REFERENCES}

CASADY, A. J., AND ANDERSON, K. L. 1952. Hybridisation, cytological, and inheritance studies of a Sorghum cross. Agron. Journ., 44, 189.

CAVANAH, J. A., AND ALEXANDER, D. E. 1963. Survival of tetraploid maize in mixed ${ }_{2} \mathrm{~N}-4 \mathrm{~N}$ plantings. Crop. Sci., 3, 329 .

Gelarier, R. P. 1958. Cytotaxonomic notes on the subsection Halepensia of the genus Sorghum. Bull. Tor. Bot. Club., 85, 49.

DOGGETT, H. 1964. Fertility improvement in autotetraploid sorghum (I). Heredity, 19, 403 .

ENDRIzZI, J. E. 1957. Cytological studies of some species and hybrids in the Eusorghums. Bot. Gaz., 119 , 1 .

ENDRIzZI, J. E. 1958. The orientation of interchange complexes and quadrivalents in Gossypium hirsutum and Eu-sorghum. Cytologia, 23, 362.

HADleY, H. H. 1953. Cytological relationships between Sorghum vulgare and $S$. halepense. Agron. Journ., 45, 139.

hadLeY, н. H. 1958. Chromosome numbers, fertility, and rhizome expression of hybrids between grain sorghum and Johnson grass. Agron. Fourn., 50, 278.

KARPER, R. E., AND CHisholm, A. T. 1936. Chromosome numbers in sorghum. Amer. Journ. Bot., 23, 269.

martin, J. H., AND LeONard, w. H. 1957. Principles of Field Crop Production. Macmillan, New York. 9th printing, p. $4^{24}$.

PARODI, L. R. 1943. Una neuva especie de sorghum cultivada en las Argentina. Rev. Argentina de Agron., Io, 361 .

RAman, v. s., AND KRishnaswamy, N. 1955. A chromosomal chimera in S. halepense. Ind. Fourn. Agric. Sci., 25, 47.

RILEY, R., AND CHAPMAN, v. 1958. Genetic control of the cytologically diploid behaviour of hexaploid wheat. Nature, 182, 713 .

SNOWDEN, J. D. 1955. The wild fodder sorghums of the section Eu-sorghum. Fourn. Linn. Soc. Lond., 55, 191.

Stebrins, G. L. 1957. Variation and Evolution in Plant. Columbia, New York, 3rd printing.

Note added in proof

Dr Hugh W. Bennett has recently confirmed that the seed-set of cross-pollinated S. halapense ranges from 70 to 90 per cent. 